\title{
Os Atrativos Turísticos de Curitiba - PR: Uma perspectiva através do Guia Brasil Quatro Rodas
}

\author{
The Tourist Attractions in Curitiba - PR: An overview by Guia Brazil Quatro \\ Rodas
}

\section{Las Atracciones Turísticas en Curitiba - PR: Una perspectiva del Guia Brasil Quatro Rodas}

\author{
Franciele Cristina Manosso ${ }^{1}$ \\ Camila Bizinelli ${ }^{2}$ \\ Cinthia Maria de Sena Abrahão ${ }^{3}$ \\ José Manoel Gonçalves Gândara ${ }^{4}$
}

Resumo: Os guias turísticos podem ser trabalhados como instrumentos relevantes para a divulgação dos destinos, pois contemplam informações sobre os atrativos, equipamentos, infraestrutura e serviços turísticos. $\mathrm{O}$ turista pode, através deste, conceber uma imagem sobre o destino que irá visitar, porque com os elementos trabalhados pelos guias, pode-se ter uma visão abrangente do que é oferecido pelo destino. O presente artigo contemplou como objetivo a análise dos atrativos turísticos da cidade de Curitiba apresentados pelo Guia Brasil Quatro Rodas nos anos de 1989, 2001, 2013, considerando como o documento apresenta a cidade para seus visitantes, analisando a descrição e o emprego de fotografias. Empregaram-se como metodologia a pesquisas bibliográfica e a análise documental, sendo a última aplicada para se verificar quais atrativos, a descrição, e se as fotografias foram empregadas na divulgação de Curitiba no Guia Brasil Quatro Rodas. Como resultados do estudo, pode-se destacar que houve um aumento no número de atrativos turísticos de Curitiba apresentados pelo Guia Brasil Quatro Rodas, sendo que, alguns destes evoluíram no que diz respeito a sua classificação, ou seja, os mesmos melhoraram em qualidade. Outra questão é a evolução da publicação na questão da apresentação dos destinos ao leitor, pois mais informações passaram a ser publicadas e, também, iniciou-se o emprego de fotografias para apresentar o destino turístico Curitiba.

Palavras-Chave: Turismo. Destinos Turísticos. Atrativos Turísticos. Guias Turísticos. Curitiba- PR.

Abstract: The tour guides books can be worked as relevant instruments for the dissemination of destinations, because encompass information about the destinations' attractions, equipment, infrastructure and tourism services. Then, the tourist can through this, conceiving a destination's image that will visit, because with the elements worked by the guides, they can get a comprehensive view of what is offered by the destination. Therefore, this article has as objective the analysis of the tourist attractions in Curitiba's city, according to Guia Brazil Quatro Rodas, presented in the years 1989, 2001, 2013. Thus, the paper aims to also highlight how the document presents the city to its visitors, analyzing the description and the photographs that are showing Curitiba to the tourist. For this, was used as methodology the literature's and documents' research, the latter being applied to observe which attractions, description, and photos

\footnotetext{
${ }^{1}$ Universidade Federal do Paraná. E-mail: francimanosso@gmail.com

2 Universidade Federal do Paraná. E-mail: ca_bizinelli@hotmail.com

3 Universidade Federal do Paraná. E-mail: cisena@terra.com.br

4 Universidade Federal do Paraná. E-mail: jmggandara@yahoo.com.br
} 
were used in the dissemination of Curitiba in the Guia Brazil. As the study results, it can be noted that there was an increase in the number of tourist attractions in Curitiba presented by Guia Brazil Quatro Rodas, and some of these have progressed in the respect of their classification, in the other words, they have improved in quality. Another issue is the publication's evolution in question the destinations' presentation to the reader, because more information came to be published, and also began to be used photos to show to the tourist the Curitiba destination.

Keywords: Tourism; Tourist Destinations; Tourist Attractions; Tourist Guide Books; Curitiba - PR.

Resumen: Los guías turísticos pueden ser trabajados como instrumentos pertinentes para la difusión de los destinos, porque incluyen información sobre los atractivos turísticos, el equipo, la infraestructura y los servicios turísticos. Así, los turistas pueden a través de este concebir una imagen del destino que irá visitar, porque con los elementos trabajados por los guías, se puede obtener una visión completa de lo que ofrece el destino. Por lo tanto, este artículo tiene como objetivo el análisis de las atracciones turísticas de la ciudad de Curitiba, presentadas pelo Guía Brasil Quatro Rodas en los años 1989, 2001, 2013. Así, el artículo destaca, también, cómo el documento se presenta la ciudad a sus visitantes, el análisis de la descripción de la ciudad y las fotografías que se muestran al turista de Curitiba. Para ello, se utilizó como metodología, la investigación de la literatura y de documentos, este último está aplicando a ver qué atracciones, descripción y fotos se utilizaron en la difusión de Curitiba en Brasil Guía Cuatro Ruedas. Como los resultados del estudio, se puede observar que hubo un incremento en el número de atracciones turísticas de Curitiba, presentadas en el Guía Brasil Quatro Rodas y algunos de ellos han progresado en su clasificación, es decir, que han mejorado en calidad. Otra cuestión es la evolución de la publicación cuando se aborda la presentación de los destinos para el lector, pues más información llegó a ser publicado, y también comenzó a ser utilizado fotos del destino turístico de Curitiba.

Palabras claves: Turismo. Destinos Turísticos. Atracción Turística. Guias Turísticos. Curitiba - PR.

\section{INTRODUÇÃO}

O guia turístico é considerado um dos meios mais utilizados para se buscar informações referentes à oferta turística de um determinado destino, logo, este consiste em um material impresso ou digital, elaborado para oferecer informações distintas ao turista, possibilitando que este compreenda previamente o que é possível desfrutar no destino turístico, bem como, pode influenciar na definição do roteiro a ser realizado (Ferreira, 2011; Torres, 2006).

Matos e Santos (2004) quando discutem os guias turísticos o compreendem como um documento carregado de complexidade, que ultrapassa as orientações de rotas e serviços aos turistas, pois os mesmos participam da construção histórica do destino turístico, divulgando ao leitor/viajante aspectos relevantes da localidade naquele período. Assim, torna-se fundamental a realização de pesquisas que abarquem as questões referentes ao avanço da apresentação dos destinos nos guias turísticos.

Diversos autores utilizam os guias turísticos em seus trabalhos a partir de diferentes vieses, fazendo com que se perceba a importância destes dentro do contexto da atividade turística. O Quadro 01 apresenta alguns artigos científicos que discutem a relevância e emprego dos mesmos dentro do turismo, para que desse modo, possa-se obter uma visão mais abrangente do que vem sendo debatido dentro da temática. Para a elaboração do Quadro 01, utilizaram-se como fonte de informação as seguintes bases de dados: Redalyc, Scopus, Portal Capes e Publicações em Turismo, sendo pesquisadas as seguintes palavras-chave: guias de turismo, guias turísticos, tourist guides e guías turísticos. 
Quadro 01 - Estado da Arte - Guias Turísticos

\begin{tabular}{|c|c|c|c|}
\hline Títulos & Autores & Revistas Científicas & Anos \\
\hline $\begin{array}{l}\text { Turismo no Litoral do Paraná: a Perspectiva do } \\
\text { Guia Brasil Quatro Rodas }\end{array}$ & $\begin{array}{l}\text { E. S. Kushano; M. L. Fillipim; J. } \\
\text { M. G. Gândara. }\end{array}$ & Rosa dos Ventos & 2013 \\
\hline $\begin{array}{l}\text { La idea de turismo en San Carlos de Bariloche a } \\
\text { través de dos guías (1938) }\end{array}$ & M. L. A Picone. & $\begin{array}{l}\text { Estudios y Perspectivas } \\
\text { en Turismo }\end{array}$ & 2013 \\
\hline $\begin{array}{l}\text { Escenario discursivo y significados implícitos en } \\
\text { una guía para los verdaderos viajeros': el caso de la } \\
\text { Guía Azul de Zaragoza. }\end{array}$ & G. Garafolo & $\begin{array}{l}\text { Pasos - Revista de } \\
\text { Turismo e Patrimonio } \\
\text { Cultural }\end{array}$ & 2012 \\
\hline $\begin{array}{l}\text { Sabores de viagem - as culinárias regionais nos } \\
\text { guias turísticos entre } 1966 \text { e } 1983 .\end{array}$ & L. P. de Morais. & Rosa dos Ventos & 2012 \\
\hline $\begin{array}{l}\text { Guias de viagem e de turismo da cidade de São } \\
\text { Paulo (1924 e 1954): hospitalidade e patrimônio }\end{array}$ & S. R. Bastos; M. R. Nova. & Turismo em Análise & 2012 \\
\hline $\begin{array}{l}\text { Descripción y narración en las primeras guías } \\
\text { turísticas de Navarra (1904-1929) }\end{array}$ & M. C. B. Zabalza & $\begin{array}{ll}\text { PASOS. } & \text { Revista de } \\
\text { Turismo y Patrimonio } \\
\text { Cultural }\end{array}$ & 2012 \\
\hline $\begin{array}{l}\text { El turismo indígena Guna (Panamá): Imaginarios y } \\
\text { regímenes de mentira de las guías turísticas } \\
\text { internacionales }\end{array}$ & X. P. Pérez & $\begin{array}{l}\text { Estudios y Perspectivas } \\
\text { en Turismo }\end{array}$ & 2012 \\
\hline $\begin{array}{l}\text { Mobile Tourist Guide - An Intelligent Wireless } \\
\text { System to Improve Tourism, using Semantic Web }\end{array}$ & S. A. El-Seoud; H. El-Sofany. & $\begin{array}{l}\text { International Journal of } \\
\text { Interactive Mobile } \\
\text { Technologies }\end{array}$ & 2011 \\
\hline $\begin{array}{lll}\text { An } & \text { innovative } & \text { mobile } \\
\text { electronic tourist guide application } & \\
\end{array}$ & $\begin{array}{l}\text { M. Kenteris; D. Gavalas; D. } \\
\text { Economou. }\end{array}$ & $\begin{array}{l}\text { Personal And } \\
\text { Ubiquitous Computing }\end{array}$ & 2009 \\
\hline $\begin{array}{l}\text { Las publicaciones divulgativas como vehículo de } \\
\text { difusión del patrimonio arqueológico: bibliografía } \\
\text { de guías arqueológicas en España 1975- } 2005 \text {. }\end{array}$ & G. G. Alcaide; C. B. Feliu. & $\begin{array}{ll}\text { Pasos: } & \text { Revista de } \\
\text { Turismo y Patrimonio } \\
\text { Cultural }\end{array}$ & 2008 \\
\hline $\begin{array}{l}\text { Distributed cognition in technology-enhanced } \\
\text { foreign language learning: Creating a web-based } \\
\text { tourist guide for London }\end{array}$ & S. Narciss; H. Korndle. & $\begin{array}{l}\text { International Journal } \\
\text { Of Psychology }\end{array}$ & 2008 \\
\hline $\begin{array}{l}\text { La construcción de la identidad andaluza percibida } \\
\text { y proyectada como reclamo turístico: los libros de } \\
\text { viaje y las guías turísticas del siglo XX (1920-1970) }\end{array}$ & M. H. Rìo; F. M. Zùñiga & $\begin{array}{l}\text { Revista HMiC: Història } \\
\text { Moderna i } \\
\text { contemporània }\end{array}$ & 2007 \\
\hline As imagens do Brasil mediadas por guias de viagem & C. B. M. C. Michelini & $\begin{array}{l}\text { Patrimônio: Lazer e } \\
\text { Turismo }\end{array}$ & 2006 \\
\hline A location-based mobile tourist guide & K. Curran ; J. Connell & $\begin{array}{l}\text { Tourism and } \\
\text { Hospitality Research }\end{array}$ & 2006 \\
\hline $\begin{array}{l}\text { Turismo e oferta gastronômica na comarca de } \\
\text { Ulloa (Galiza): Análise de uma experiência de } \\
\text { desenvolvimento local }\end{array}$ & X. Pereiro, S. P. Conde. & $\begin{array}{ll}\text { Pasos: Revista de } \\
\text { Turismo y Patrimonio } \\
\text { Cultural }\end{array}$ & 2005 \\
\hline Os guias turísticos em Berlim & I. A. F. Barreira & Tempo Social & 2005 \\
\hline $\begin{array}{l}\text { La política de la mirada: las representaciones de las } \\
\text { guías turísticas de Bogotá en los treinta }\end{array}$ & S. M. Gómez & $\begin{array}{l}\text { Anuario Turismo y } \\
\text { Sociedad }\end{array}$ & 2005 \\
\hline $\begin{array}{l}\text { Os Guias de Turismo e a emergência do turismo } \\
\text { contemporâneo em Portugal (dos finais do século } \\
\text { XIX às primeiras décadas do século XX) }\end{array}$ & $\begin{array}{l}\text { A. C. Matos, M. L. F. N. } \\
\text { Santos. }\end{array}$ & $\begin{array}{l}\text { Scripta Nova: Revista } \\
\text { electrónica de } \\
\text { geografía y ciencias } \\
\text { sociales }\end{array}$ & 2004 \\
\hline $\begin{array}{l}\text { Projeto e produção cartográfica do Guia Turístico } \\
\text { eletrônico das represas paulistas para internet }\end{array}$ & $\begin{array}{l}\text { K. C. L. Oliveira; M. M. S. } \\
\text { Decanini }\end{array}$ & $\begin{array}{l}\text { Revista Brasileira de } \\
\text { Cartografia }\end{array}$ & 2002 \\
\hline $\begin{array}{l}\text { The role of adaptive hypermedia in a context- } \\
\text { aware tourist guide }\end{array}$ & $\begin{array}{l}\text { K. Cheverst; K. Mitchell; N. } \\
\text { Davies. }\end{array}$ & $\begin{array}{l}\text { Communications Of } \\
\text { The ACM Journal }\end{array}$ & 2002 \\
\hline
\end{tabular}

Fonte: Os Autores (2014). 
Buscando elucidar a questão problema de pesquisa "Como o Guia Brasil Quatro Rodas apresenta, em seu conteúdo, a cidade de Curitiba?" o presente artigo tem como objetivo central a análise dos atrativos turísticos da cidade de Curitiba apresentados conforme o Guia Brasil Quatro Rodas nos anos de 1989, 2001, 2013, considerando como estes documentos retratam a cidade para seus visitantes, analisando a descrição e avaliação destes e o emprego de imagens da cidade dentro das publicações. O uso do Guia Brasil Quatro Rodas para a concretização da pesquisa ocorreu devido à sua importância frente à demanda e ao trade turístico que o emprega tanto para a escolha (turista) quanto para a divulgação (trade) do destino turístico (Villanueva, 2010).

Os temas a serem discutidos dentro do estudo proposto enfatizam os guias turísticos e os atrativos turísticos da cidade de Curitiba. Empregaram-se como metodologia a pesquisas bibliográfica e a análise documental, sendo a última aplicada para se verificar quais atrativos, a descrição do destino, e se as fotografias foram inseridas para a divulgação de Curitiba no Guia Brasil Quatro Rodas.

\section{GUIAS TURÍSTICOS}

A crescente necessidade de informações por parte dos turistas a respeito do destino que será visitado estimula o lançamento dos guias turísticos, que compilam informações sobre os produtores dos serviços e produtos turísticos, sendo estes: restaurantes, hotéis, casas de shows e até mesmo os atrativos turísticos (Ferreira, 2011; Barreira, 2005. Picone, 2013). Matos e Santos (2004, p. 11) frisam que:

\footnotetext{
Os guias de viagens inserem-se numa literatura utilitária e pedagógica que visa dar àqueles a quem se dirige uma série de indicações sobre as viagens a empreender e sobre os espaços a visitar. Assim, nos vários guias de viagem que foram surgindo ao longo dos tempos às informações sobre a forma de viajar e os lugares a visitar correm a par com as informações de caráter histórico sobre os vários lugares ou monumentos. Ainda no século XVII surgem obras especializadas dirigidas aos viajantes, mas é no século XVIII que se desenvolve a publicação de guias de viagens [...].
}

Santulli (2010) discorre que o guia turístico, desde seu surgimento, tem como característica ser prescritivo, ou seja, busca informar e preparar o turista quando este procura ideias sobre determinado destino conduzindo-o a fazer uma viagem satisfatória. Os guias convidam os turistas a uma viagem no campo da imaginação, pois com o contato com os textos e imagens, a leitura do guia turístico parece evocar o sonho do leitor viajante (Fraise, Pomporgnac, Pailan, 1997; Bastos e Nova, 2012).

Moirand (2004) ressalta que o guia turístico se pauta em fazer o turista conhecer o destino, fazer com que ele consiga enxergá-lo, sendo que, ainda o guia pode ser uma forma de dizer ao turista o que fazer quando se encontra na localidade. Logo, os guias devem conter além de imagens, textos que não devem ser considerados apenas um conjunto de signos ou elementos que se remetem a conteúdos ou representações, mas também como uma maneira de apresentar 
sistematicamente os destinos divulgados pelos guias (Foucault, 1969; Fairclough, 1995; Garafolo, 2012; Morais, 2012).

Michelini (2006) e Fernandes, Yamamoto e Júnior (2011) apontam que a presença de imagens fotográficas dos atrativos turísticos, das paisagens, da gastronomia, dos eventos faz com que se conceba uma maneira de representação do destino turístico, mostrando ao turista a existência de elementos importantes a serem visitados, pois cada um lhe proporcionará uma experiência nova. Nova e Bastos (2008) destacam que os guias devem ser utilizados como uma forma de realizar uma mediação entre o turista e o espaço público, ofertando ao visitante as informações necessárias para que sejam conhecidas as características do destino que se irá visitar. Dessa forma, pode-se afirmar que os guias turísticos são 'documentos' que apresentam informações, consideradas completas, para seu público alvo, podendo ainda, serem avaliados como responsáveis pela composição do imaginário pessoal a respeito do destino a ser visitado (Ferreira, 2011; Curran e Connel, 2006; Zabalza, 2012).

Castro (2006) discute a característica dinâmica dos guias, principalmente o que se refere, a evolução da experiência turística frente às mudanças que ocorrem dentro da localidade que está sendo divulgada, ou seja, os guias progridem a partir do que vem sendo apresentado pelas cidades. Segundo a perspectiva do autor, esses aspectos podem ser observados quando se analisam os guias existentes na década de 1930 que, por exemplo, destacavam as praças e que nos dias atuais destacam como atrativos as praias ou o centro da cidade. Isso ocorre devido às mudanças que sucedem na cidade, fazendo com que a atividade turística se altere conjuntamente. Castro (2006, p. 84) afirma também que "as narrativas e imagens associadas ao turismo são, portanto, uma importante via de acesso à história e à geografia culturais de uma cidade".

Bassanezi (1996) enfatiza que os guias veiculam o que pode ser considerado o 'mundo da cidade', sendo que seu conteúdo se relaciona com a história recente do local, porque devem acompanhar as transformações ocorridas no espaço, delimitado como cidade, para que não percam seu público-alvo. A mesma autora afirma, ainda, que os guias são capazes de levar as pessoas a conhecer determinado local, influenciando seus gostos, opiniões, padrões de consumo, entre outros.

A respeito da discussão centrada na criação de imagens e na influência que os guias turísticos podem acarretar no comportamento do consumidor, Mariani (1993, p. 33) considera que "é preciso considerá-lo do ponto de vista do imaginário de uma época: pois este irá se comportar como uma prática social produtora de sentido, mas também, direta ou indiretamente, veiculará as vozes constitutivas daquele imaginário". Torres $(2006$, p.6) salienta a questão do imaginário criado pelos guias quando cita que: “(...) as representações das cidades apresentadas pelos veículos de comunicação acabam por fixarem cenas, retratar, ilustrar, reproduzir e sintetizar a realidade de uma cidade".

Logo, deve-se ter consciência que uma das principais etapas para o planejamento de uma viagem é a busca por informações por parte dos turistas, sendo que esta também pode ocorrer no decorrer da viagem, sendo assim, faz-se necessário que os guias contenham informações 
relevantes e reais sobre o destino que está 'divulgando', para que dessa maneira, o turista não crie expectativas que se encontrem fora do contexto que ocorre dentro do espaço urbano, considerado como destino turístico (Ferreira, 2011).

Os guias turísticos tornam-se essenciais para os turistas, pois como ressalta Engel (1995) é o reconhecimento das necessidades por parte do consumidor, que leva o indivíduo a iniciar a busca por informações, ativando o conhecimento arquivado na memória, representado pela busca interna, ou estimulando-o a adquirir informações no ambiente, representado pela busca externa.

A partir do que foi discutido até o presente momento, cabe destacar a importância do Guia Brasil Quatro Rodas, que teve sua primeira edição publicada em 1966, dentro do contexto das viagens brasileiras. A publicação contém, em suas páginas iniciais, um roteiro de como utilizála, além das informações referentes à metodologia aplicada para a elaboração do documento (Kushano, Filippim e Gândara, 2013). Tendo como base o que o documento de 2013, o guia destaca como atrativos turísticos:

Praias, igrejas, museus, fortes, construções históricas, centros culturais, parques nacionais, turismo de aventura, passeios, cachoeiras. Para classificar cada atração num grau de uma a cinco estrelas, nossos repórteres visitam cada lugar como se fossem turistas comuns. Então, observam detalhes como sinalização, conservação, acessibilidade, existência de guias locais quando pertinente, além do interesse histórico, artístico, arquitetônico ou natural. As atrações, dentro de cada tipo, são listadas por ordem de estrelas. Apenas as praias não seguem este padrão - elas aparecem listadas do sul para o norte (exceto nas ilhas). As informações sobre balneabilidade do litoral brasileiro são fornecidas pelos órgãos estaduais competentes. O GUIA BRASIL 2013 considera as medições feitas no verão de 2012.

Além da compreensão de como a classificação é realizada, cabe destacar como é apresentado o grau de interesse ao leitor, que se utiliza de estrelas para mostrar ao viajante a importância e até mesmo a qualidade de determinado atrativo dentro do destino.

Figura 01 - Classificação dos Atrativos Turísticos

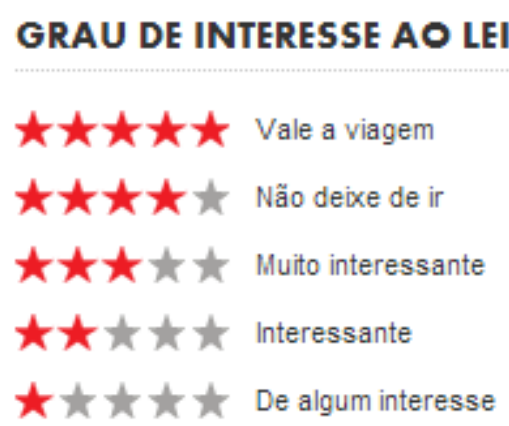

Fonte: Guia Quatro Rodas Brasil (2013)

Com o que foi discutido até o presente momento pode-se perceber a importância da análise dos guias turísticos para a divulgação dos atrativos, bem como, para o processo de decisão do turista ao escolher determinado destino. Isto posto, o trabalho contemplará, no próximo 
tópico, a discussão sobre os atrativos turísticos, focando-se principalmente naqueles presentes na cidade de Curitiba, Paraná.

\section{OS ATRATIVOS TURÍSTICOS DE CURITIBA}

Os destinos turísticos são definidos como um território constituído por ofertas relacionadas ao turismo, e reconhecido pelo mercado como um receptáculo para os turistas, os mesmos têm como componentes fundamentais os recursos ou atrativos turísticos, instalações, serviços, uma rede de infraestrutura e, sobretudo hospedagem e alimentação (Cooper et al, 2001; Valls, 1996).

Nesse sentido, cabe destacar os atrativos turísticos, que segundo Cooper et al (2001) devem ser conceituados como aqueles que compõem a oferta turística, considerada agregada e, que estão, em algum ponto, relacionados com a história e a cultura dos lugares, podendo estes serem prédios, igrejas, ruínas arqueológicas, palácios, casas e até mesmo cidades, sendo caracterizados como atrativos turísticos históricos. Entretanto, há os atrativos construídos com a funcionalidade específica de entretenimento, citando-se como exemplos, os parques temáticos e de lazer, locais destinados ao esporte e a recreação.

Corroborando o que foi discutido anteriormente, a EMBRATUR (1992) define os atrativos turísticos como uma forma de representação dos lugares, objetos e até mesmo de acontecimentos que geram interesse no visitante, podendo-se acrescentar em tal categoria os hábitos e costumes dos povos, considerados patrimônios imateriais relevantes dentro da atividade turística. A partir do que foi exposto sobre os atrativos turísticos e a importância destes dentro do turismo, cabe agora discutir a atividade turística em Curitiba, destacando os atrativos turísticos presentes na cidade, bem como, o contexto destes dentro do planejamento e da evolução da localidade.

De acordo com Rechia (2005), Fernandes, Gândara e Souza (2011), Bonfim e Bahl (2012), Curitiba foi divulgada frequentemente como modelo de eficiência na gestão pública, e ganhou destaque no cenário nacional e internacional, por ser considerada uma 'cidade-modelo', com ênfase para os conceitos de 'cidade com qualidade de vida', 'cidade ambientalmente correta', 'capital ecológica', entre outras. Essa distinção ocorre em função das experiências urbanas implantadas para o planejamento da cidade, sendo estas consideradas inovadoras e criativas.

Logo, deve-se enfatizar que a imagem que a cidade busca divulgar foi aprimorada por meio dos projetos lançados pelo poder local, que têm como objetivo atribuir à cidade uma forma e identidade própria e específica, centrada principalmente, na oferta de espaços destinados as experiências no âmbito do lazer, da cultura e do esporte (Recchia, 2005). Esse fato é corroborado pelo que cita a Prefeitura Municipal de Curitiba (2005) quando menciona que uma das particularidades para a implantação da política de áreas verdes na cidade se relaciona, precisamente, com a afirmação da recreação e do lazer como fatores indispensáveis ao equilíbrio físico e mental dos habitantes de Curitiba, bem como, para o desenvolvimento destes. Contudo, deve-se destacar que essas áreas não foram instituídas unicamente para esse propósito, pois 
algumas delas têm sua implantação relacionada com os problemas ambientais presentes em alguns pontos da cidade.

Os marcos históricos relacionados ao surgimento dos atrativos turísticos de Curitiba, pelos quais se pode perceber de que maneira a cidade evoluiu turisticamente ao longo dos anos. Tais são salientados no Quadro 02, onde é apresentada uma linha do tempo contendo o ano de surgimento dos atrativos da cidade.

\begin{tabular}{|c|c|}
\hline Ano & Acontecimento \\
\hline 1693 & Fundação da Cidade \\
\hline 1873 & Estrada da Graciosa \\
\hline 1878 & Colonização mais intensa de Santa Felicidade \\
\hline 1885 & Inauguração da Ferrovia Curitiba - Paranaguá. \\
\hline 1886 & Criação do Passeio Público ( $1^{\circ}$ Parque de Curitiba) \\
\hline 1889 & Nomeação da Praça Tiradentes \\
\hline 1916 & Paço da Liberdade \\
\hline 1954 & Teatro Guaíra \\
\hline 1971 & Teatro Paiol \\
\hline \multirow{4}{*}{1972} & Parque São Lourenço \\
\hline & Parque Barreirinha \\
\hline & Parque Barigui \\
\hline & Rua das Flores \\
\hline 1979 & Parque Regional do Iguaçu (Zoológico e Parque Náutico) \\
\hline 1980 & Bosque João Paulo II \\
\hline 1982 & Museu Ferroviário \\
\hline 1988 & Parque Bacacheri \\
\hline \multirow[t]{3}{*}{1991} & Parque Passaúna \\
\hline & Torre Panorâmica \\
\hline & Rua 24 Horas \\
\hline \multirow[t]{2}{*}{1992} & Ópera de Arame \\
\hline & UNILIVRE - Universidade Livre do Meio Ambiente \\
\hline \multirow[t]{3}{*}{1994} & Jardim Botânico \\
\hline & Parque Tingui \\
\hline & Linha Turismo \\
\hline \multirow[t]{2}{*}{1996} & Bosque Alemão \\
\hline & Parque Tanguá \\
\hline 2000 & Projeção da Cidade para receber turistas. \\
\hline 2002 & Museu Oscar Niemeyer \\
\hline
\end{tabular}

Fonte: Os Autores com base em Ribeiro (2005); Ribeiro e Silveira (2006); Prefeitura de Curitiba (2013); Pedron (2013).

O Quadro 02 demonstra a evolução dos atrativos existentes em Curitiba, podendo-se enfatizar o grande número de parques presentes na cidade e considerados atrativos turísticos. Esse fato é confirmado por Pedron (2013) quando cita que os parques se tornaram elementos que identificam a cidade, e se converteram em meio de caracterização e diferenciação da mesma, principalmente ao apresentar e valorizar o ambiente natural e cultural, para que desse modo, tanto a comunidade local quanto os turistas se sintam 'conectados' com os atrativos presentes na cidade. Nesse sentido, García (1996) avalia que os parques são utilizados para enriquecer a 
imagem da cidade que começa a se fortalecer em 1990, ou seja, a Curitiba - Capital Ecológica, pois a cidade é vista como uma história de sucesso dentro de um país que, frequentemente, fracassa nas questões ambientais.

Cabe destacar que a cidade de Curitiba, atualmente, conta com 21 parques e 16 bosques, sendo os parques os atrativos mais visitados pelos turistas, fato este corroborado pelo Instituto Municipal de Turismo de Curitiba (2011) e Viaje Curitiba (2012) e apresentado no Quadro 03.

Quadro 03 - Porcentagem de Visitantes nos Atrativos de Curitiba - Linha Turismo

\begin{tabular}{|l|c|}
\hline \multicolumn{1}{|c|}{ Atrativo } & Porcentagem de Visitantes \\
\hline Jardim Botânico & $20,93 \%$ \\
\hline Ópera de Arame & $15,48 \%$ \\
\hline Praça Tiradentes & $11,53 \%$ \\
\hline Parque Tanguá & $7,11 \%$ \\
\hline Museu Oscar Niemeyer & $6,17 \%$ \\
\hline Torre Panorâmica & $5,78 \%$ \\
\hline Santa Felicidade & $5,20 \%$ \\
\hline Museu Ferroviário & $4,74 \%$ \\
\hline Parque Barigui & $2,81 \%$ \\
\hline Rua das Flores & $2,50 \%$ \\
\hline Bosque Alemão & $2,44 \%$ \\
\hline Rua 24 Horas & $2,17 \%$ \\
\hline Unilivre & $2,06 \%$ \\
\hline Teatro Guaíra/UFPR & $1,54 \%$ \\
\hline Bosque do Papa/Memorial Polonês & $1,52 \%$ \\
\hline Passeio Público/Memorial Árabe & $1,36 \%$ \\
\hline Setor Histórico & $1,30 \%$ \\
\hline Memorial Ucraniano & $1,08 \%$ \\
\hline Parque Tingui & $0,64 \%$ \\
\hline Paço da Liberdade & $0,40 \%$ \\
\hline Parque São Lourenço & $0,26 \%$ \\
\hline Teatro Paiol & $0,15 \%$ \\
\hline Centro Cívico & $0,07 \%$ \\
\hline Portal Italiano & $0 \%$ \\
\hline Fonte: IMT (2011);Viaje Curitiba (2012). Adaptado & $0504 \%$, \\
\hline
\end{tabular}

Fonte: IMT (2011); Viaje Curitiba (2012). Adaptado pelos autores, 2013

Entretanto, cabe destacar, que apesar de se fundamentar o turismo, preponderantemente, nos parques existentes na cidade, Curitiba, ainda, busca oferecer aos seus visitantes outras opções de lazer, sendo estas enquadradas na categoria do Turismo Cultural. Nesse sentido, segundo o Instituto Municipal de Turismo (2012) Curitiba contempla uma variada oferta de museus e espaços e eventos culturais, tais como, o Museu Oscar Niemeyer, conhecido como 'Museu do Olho', o Centro Histórico, conhecido como "Largo da Ordem', o Paço da Liberdade reformado durante as comemorações dos 316 anos da cidade, e os eventos relacionados à cultura, sendo estes: o Festival de Teatro de Curitiba, a Oficina de Música e o Natal Encantado de Curitiba, realizados todos os anos na cidade. O Instituto Municipal (2012) destaca, também, a existência de atrativos que não se localizam em Curitiba, mas que são considerados 
importantes na atividade turística da mesma, sendo estes: o passeio de Trem rumo ao Litoral do Paraná e a Estrada da Graciosa.

Rechia (2005) aponta a relevante estratégia urbanística que Curitiba utilizou ao agregar paisagens naturais, modelos arquitetônicos modernos e projetos culturais nos espaços públicos destinados às práticas de lazer e de turismo, podendo-se destacar que a coerência da linguagem arquitetônica desses ambientes passa ao turista e ao morador à imagem de uma 'cidade que deu certo', fazendo com que esse fique satisfeito ao visitar a cidade.

A partir da década de 90, a gestão municipal passou a desenvolver projetos destinados ao transporte turístico da cidade, assim, cabe salientar a Linha Turismo, gerida pela URBS Urbanização de Curitiba S.A., que proporciona ao visitante um circuito que contempla 24 atrativos turísticos da cidade, fazendo com que se conheça de maneira abrangente e em apenas um dia os principais pontos de interesse para a visitação (Silva, 2012; Gândara, Albach, Vieira, 2008; Custódio, 2006; URBS, 2012). Ainda, abordando a questão do transporte da cidade Ramos, Gândara e Tramontin (2008) discutem o impacto das ações urbanas que contribuíram para o aumento da demanda turística utilizando-se, como exemplo, as soluções de transporte coletivo que trouxe à cidade grupos específicos que gostariam de conhecer seu funcionamento.

A partir de tudo que foi abordado, o próximo tópico discutirá a metodologia de pesquisa utilizada para o alcance do objetivo proposto.

\section{METODOLOGIA DE PESQUISA}

O estudo realizado teve como objetivo central análise dos atrativos turísticos da cidade de Curitiba apresentados pelo Guia Brasil Quatro Rodas nos anos de 1989, 2001, 2013, considerando como o documento apresenta a cidade para seus visitantes, analisando a descrição e o emprego de fotografias. Os referidos anos foram escolhidos para que se obtenha uma perspectiva mais abrangente das mudanças pelas quais a cidade de Curitiba passou ao que diz respeito a sua divulgação nos guias turísticos nos últimos 24 anos, utilizando-se para tal, intervalos equivalentes há 12 anos entre os guias. Desta forma, o artigo buscou, ainda, destacar como o documento apresenta a cidade para seus visitantes, analisando a avaliação e descrição destes e o emprego de imagens da cidade dentro das publicações.

Logo, faz-se essencial apresentar a metodologia de pesquisa utilizada para a concretização do estudo em questão. Primeiramente, pode-se afirmar que a mesma se caracteriza como uma pesquisa aplicada, pois como afirma Dencker (1998), esta tem como premissa desenvolver novos conhecimentos, e até mesmo um aprofundamento dos já existentes, podendose assim expandir o que vem sendo discutido sobre a temática. Com relação aos objetivos da pesquisa, pode-se afirmar que a mesma tem caráter exploratório, pois como pondera Popper (1974) esta tem como intuito elucidar e, ainda, transformar conceitos e ideias, com vistas a estabelecer hipóteses pesquisáveis. 
No que se refere aos procedimentos técnicos utilizados, tem-se a pesquisa bibliográfica e documental, sendo que a primeira permitiu um grau de amplitude de pesquisa maior (Dencker, 1998). Os temas pesquisados para dar base ao referencial teórico da pesquisa foram guias turísticos e os atrativos turísticos de Curitiba. A metodologia de pesquisa baseada na análise documental empregou, como fonte única, os guias turísticos utilizados como embasamento na elucidação da questão problema de pesquisa "Como o Guia Brasil Quatro Rodas apresenta a cidade de Curitiba?".

O emprego da pesquisa documental é corroborado por Cellard (2008) quando cita que o documento escrito se constituiu em uma fonte relevante para o pesquisado, pois pode ser considerado insubstituível na reconstituição de um passo relativamente distante por representar a quase totalidade dos vestígios da atividade humana em determinadas épocas. O mesmo autor discorre que a análise de documentos favorece a observação do processo de maturação ou de evolução de indivíduos, grupos, conceitos, conhecimentos, comportamentos, mentalidades e práticas (Cellard, 2008). Para a presente pesquisa foram analisadas, dentro do contexto da pesquisa documental, as seguintes questões:

Quadro 04 - Objetivos de Análise

\begin{tabular}{|l|l|}
\hline Atrativos Turísticos & $\begin{array}{l}\text { Analisaram-se quais são os atrativos divulgados pelo } \\
\text { Guia Brasil Quatro Rodas, bem como, a classificação } \\
\text { que o documento impõe aos atrativos. }\end{array}$ \\
\hline Imagens Fotográficas & $\begin{array}{l}\text { Buscou-se analisar se os guias, nos anos pesquisados, } \\
\text { apresentavam fotografias do destino turístico } \\
\text { Curitiba, investigando a 'evolução' deste neste } \\
\text { quesito. }\end{array}$ \\
\hline Descrição do Destino & $\begin{array}{l}\text { Averiguaram-se quais foram às descrições } \\
\text { apresentadas pelos guias, nos anos pesquisados, a } \\
\text { cerca da cidade de Curitiba, ou seja, que aspectos } \\
\text { foram levados em consideração para serem } \\
\text { apresentados aos turistas. }\end{array}$ \\
\hline
\end{tabular}

Fonte: Os autores (2014)

Com a apresentação do Quadro 04, pode-se obter uma visão mais abrangente dos objetivos da presente pesquisa. Uma questão a ser levada em consideração, sob a perspectiva da presente pesquisa, é que as questões apresentadas pelos guias analisados não se relacionam, de maneira direta, com aquilo que o governo divulga de Curitiba, pois a publicação possui um cunho comercial e elege, de acordo com seus próprios parâmetros, buscando atender à perspectiva e satisfação dos turistas, o que os técnicos do Guia julgam de interessante que pode ser encontrado no destino turístico, não se baseando, necessariamente, naquilo que é apresentado pelos órgãos governamentais responsáveis pela atividade turística, como mais atrativo para se visitar na cidade. O próximo tópico apresentará tanto os resultados da pesquisa quanto a discussão e apreciação dos mesmos. 


\section{ANÁLISE E DISCUSSÃO DOS RESULTADOS}

Com a apreciação de tudo que foi discutido até o presente momento, devem-se destacar os resultados oriundos da análise do Guia Brasil Quatro Rodas, dos anos de 1989, 2001 e 2013, que se refere aos atrativos da cidade de Curitiba, cidade localizada no estado do Paraná. 0 diagnóstico será dividido em dois pontos, sendo que o primeiro aspecto a ser discutido é a descrição de Curitiba e as imagens fotográficas apresentadas pelos guias, avaliando de que forma a citada vem sendo apresentada aos turistas. Seguidamente, serão apresentados os resultados oriundos das análises dos atrativos turísticos da cidade, sendo ponderada a aparição de determinada atração, assim como, a sua classificação dentro do Guia.

\subsection{Descrição de Curitiba e imagens fotográficas}

Conforme se observa no Quadro 05, a descrição de Curitiba nas três edições do Guia Brasil, inexistente na primeira delas, passou a enfatizar o ideário de 'cidade ecológica', em 2001, para assumir em 2013, uma tônica cultural, descolada, ressaltando aspectos da qualidade de vida.

Quadro 05 - Descrição de Curitiba no Guia Quatro Rodas Brasil

\begin{tabular}{|c|c|c|}
\hline 1989 & 2001 & 2013 \\
\hline $\begin{array}{l}\text { O Guia não apresenta nenhuma } \\
\text { descrição de Curitiba. }\end{array}$ & $\begin{array}{l}\text { 'Conhecida por soluções } \\
\text { urbanas inovadoras, foi a } \\
\text { primeira cidade a ter calçadão } \\
\text { (trecho da Rua Xv de Novembro } \\
\text { batizada de Rua das Flores, ao } \\
\text { lado da Boca Maldita } \\
\text { (tradicional ponto de encontro } \\
\text { dos curitibanos), uma Rua } 24 \\
\text { horas, ciclovias, bom serviço de } \\
\text { transporte coletivo e grandes } \\
\text { parques. Com } 55 \mathrm{~m}^{2} \text { de área } \\
\text { verde por habitante (a } \\
\text { Organização Mundial da Saúde } \\
\text { recomenda } 16 \text { m }^{2} \text { ), Curitiba é } \\
\text { praticamente cercada por } \\
\text { parques e bosques. Apresenta } \\
\text { clima temperado, com inverno } \\
\text { rigoroso e eventuais geadas'. }\end{array}$ & $\begin{array}{l}\text { 'Com belos parques e praças, } \\
\text { Curitiba convida para } \\
\text { programas ao ar livre. A } \\
\text { juventude descolada } \\
\text { transformou o jardim do Museu } \\
\text { Oscar Niemeyer em seu novo } \\
\text { reduto para as tardes de } \\
\text { domingo -e apelidou o local de } \\
\text { Parcão. Os tradicionais Jardim } \\
\text { Botânico e parques Barigui e } \\
\text { Tanguá também seguem } \\
\text { contribuindo, com maestria, } \\
\text { para a cidade receber o título } \\
\text { de 'capital ecológica do Brasil'. } \\
\text { Mesmo no inverno, vale } \\
\text { enfrentar o frio e bater perna no } \\
\text { centro histórico. Todos os } \\
\text { domingos do ano tem feirinha } \\
\text { no Largo da Ordem, com } \\
\text { artesanato e boa comida. Nos } \\
\text { sábados, as barraquinhas de } \\
\text { objetos antigos tomam a Praça } \\
\text { da Espanha. A gastronomia da } \\
\text { cidade tem polo crescente na } \\
\text { divisa entre os bairros Alto da } \\
\text { XV e Cabral, com destaque para } \\
\text { a Fornearia Copacabana'. }\end{array}$ \\
\hline
\end{tabular}

Fonte: Os autores (2013) 
Pode-se notar a ênfase dada na divulgação dos parques urbanos localizados na cidade. 0 que corrobora com Rechia (2005), Ribeiro e Silveira (2006) quando abordam que a imagem de Curitiba busca atribuir um conceito que se conforme em uma identidade própria, ou seja, centrada na oferta destinada às experiências no âmbito do lazer, da cultura e do esporte, podendo-se destacar, nesse âmbito, os parques urbanos presentes na maior parte da cidade. Assim, a Prefeitura Municipal de Curitiba (2005) menciona que a implantação das áreas verdes, está intrinsecamente relacionada com a afirmação do lazer e da recreação como fatores indispensáveis para o equilíbrio físico e mental dos habitantes de Curitiba.

Além dos aspectos relacionados aos parques, Curitiba também é divulgada através da atuação diferenciada de sua gestão pública, com suas características enfatizadas, divulgação esta ganhando destaque tanto dentro do cenário nacional quanto internacional. Essas distinções são fruto das experiências urbanas implantas pelo planejamento da cidade, que são consideradas inovadoras e criativas (Rechia, 2005; García, 1996). O Guia de 2001 faz alusão à questão abordada, anteriormente, quando cita que Curitiba é 'Conhecida por soluções urbanas inovadoras [...]', quando se discute tanto o planejamento urbano da cidade quanto a criação de parques para o entretenimento da população.

Outro aspecto interessante se refere ao fato de que na edição de 1989, como na de 2001, a apresentação de Curitiba é realizada sem adição de imagens.

Figura 02 - Página de Apresentação do Guia Brasil Quatro Rodas: 1989 e 2001
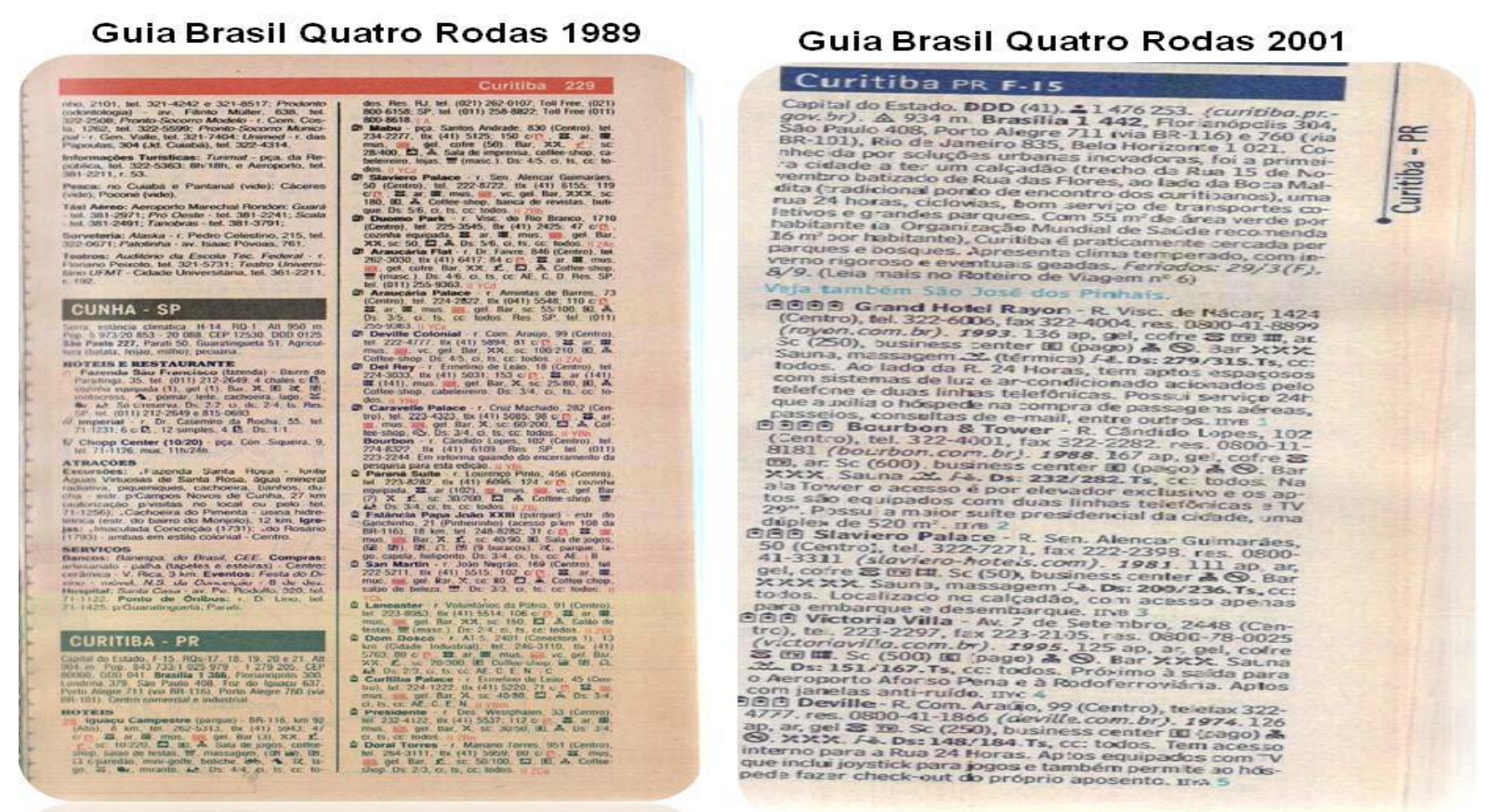

Fonte: Guia Brasil Quatro Rodas (1989; 2001).

Observando a Figura 02 fica evidente que existem apenas informações escritas sobre os principais equipamentos, atrativos, infraestrutura. Contudo, na Figura 03 apresentam-se as páginas que introduzem Curitiba no guia, mostrando ao turista as características da cidade, as 
curiosidades e imagens fotográficas dos principais atrativos existentes no destino. Deve-se salientar que o emprego das figuras apresentadas no trabalho, não tem como escopo apresentar o conteúdo das fotografias divulgadas pelo Guia Brasil Quatro Rodas sobre a cidade de Curitiba, e sim fazer alusão a 'evolução' deste quanto ao emprego de imagens fotográficas em suas edições.

Figura 03 - Página de Apresentação do Guia Brasil Quatro Rodas: 2013
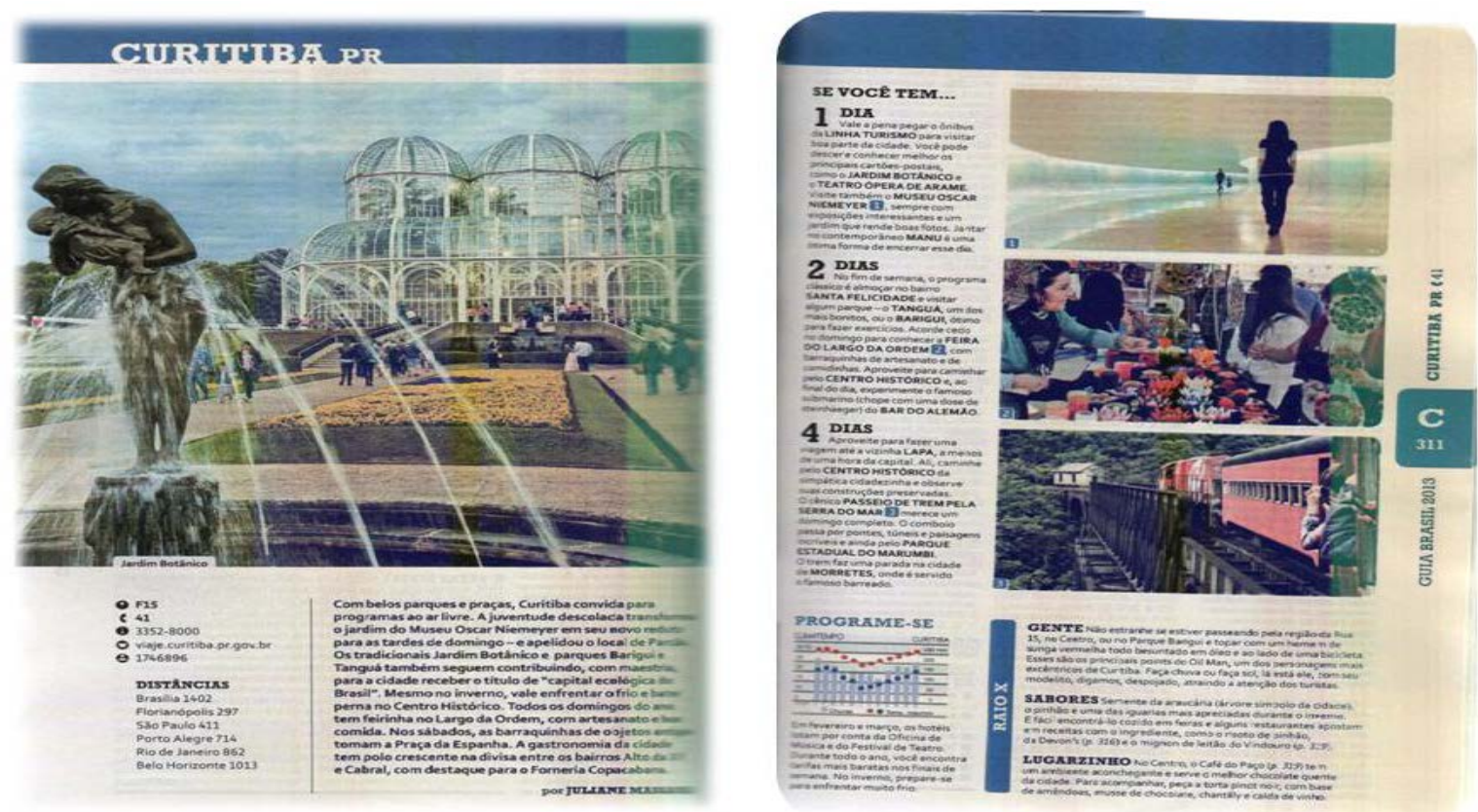

Fonte: Guia Brasil Quatro Rodas (2013)

Pode-se perceber que o Guia Brasil Quatro Rodas mudou a forma de apresentar o destino Curitiba ao seu leitor/turista, buscando prover além de descrições e informações sobre o destino, imagens que retratem e agucem o imaginário do turista. Matos e Santos (2004) reforçam a ideia de que os guias de viagem inserem-se dentro de uma literatura considerada utilitária que visa dar aos turistas uma série de indicações sobre viagens e os espaços que o mesmo deseja visitar.

Além disso, Fraise, Pomporgnac e Pailan (1997) salientam a importância do guia para a criação do imaginário do turista sobre determinado destino, pois é a partir do contato com os textos, as imagens, bem como, com a leitura do guia turístico que se evoca o sonho e a imaginação do leitor quanto ao destino que se pretende visitar. Ao analisar as mudanças dos guias turísticos Brasil Quatro Rodas quanto a esse aspecto comparando-se as informações contidas na introdução da cidade de Curitiba em cada documento estudado $(1989,2001,2013)$, se pode identificar que os editores começaram a se preocupar em motivar ainda mais a imaginação do leitor/turista.

Segundo Foucault (1969); Fairclough (1995); Garafolo (2012) os guias devem conter imagens e textos que precisam ser considerados elementos que remetem a conteúdos e representações, apresentando sistematicamente os destinos divulgados. Assim, ao analisar os conteúdos relacionados à Curitiba, apresentados pelo Guia Brasil Quatro Rodas, pode-se afirmar que o mesmo encontra-se em consonância com o que os autores, citados anteriormente, propagam ao que se refere ao conteúdo do guia turístico, pois apesar das duas primeiras edições 
(1989 e 2001) não conterem fotos elas buscam mostrar ao leitor o que a cidade tem a oferecer. Porém, a edição mais atual do Guia (2013) consegue aliar as imagens e as informações, para que o turista consiga 'construir' o imaginário frente à cidade (Bassanezi, 2006). A partir de tudo que foi discutido nesse tópico o próximo abordará de maneira efetiva os atrativos turísticos de Curitiba apresentados no Guia Brasil Quatro Rodas dos anos de 1989, 2001 e 2013.

\subsection{Atrativos Turísticos de Curitiba segundo o Guia Brasil Quatro Rodas}

A Tabela 01 mostra as mudanças quanto ao número de atrativos que aparecem em determinada categoria, percebe-se que tanto em 1989 quanto em 2013 o Guia Brasil Quatro Rodas busca ressaltar os atrativos culturais presentes na cidade, enfatizando as excursões e passeios ofertados, bem como, os museus existentes. O ano de 2001 destaca os atrativos referentes aos aspectos naturais, ou seja, os parques, praças e bosques.

Tabela 01 - Categoria de Atrativos de Curitiba - Guia Brasil Quatro Rodas

\begin{tabular}{|c|c|c|c|}
\cline { 2 - 4 } \multicolumn{1}{c|}{} & $\mathbf{1 9 8 9}$ & $\mathbf{2 0 0 1}$ & $\mathbf{2 0 1 3}$ \\
\hline Categoria & Quantidade & Quantidade & Quantidade \\
\hline Compras & 03 & 02 & 04 \\
\hline Eventos & 00 & 01 & 04 \\
\hline Construções Histórica/Setor Histórico & 05 & 04 & 01 \\
\hline Igrejas & 03 & 02 & 00 \\
\hline Museus & 10 & 06 & 05 \\
\hline Parques/Praçase Bosques & 07 & 12 & 09 \\
\hline Passeiose Excursões & 09 & 05 & 11 \\
\hline Outros & 00 & 00 & 01 \\
\hline
\end{tabular}

Fonte: OS autores (2013)

Com a análise da tabela anterior pode-se inferir que as principais categorias de atrativos divulgados são: as excursões e passeios, os museus e os parques e praças existentes em Curitiba. A importância dessas categorias é corroborada pela pesquisa de demanda de Curitiba, onde são apresentados os principais atrativos visitados na cidade, sendo contemplada a maioria dos atrativos presentes nas categorias em destaque, os quais: Jardim Botânico, Ópera de Arame e Praça Tiradentes que contemplam a categorias de Parques e Praças; Museu Oscar Niemeyer, Museu Paranaense e o Setor Histórico, que abrangem as categorias dos museus e das construções históricas; e o Bairro de Santa Felicidade, que se enquadra na categoria de passeios; entre outros atrativos citados pelo guia e apresentados na pesquisa da demanda da cidade (Viaje Curitiba, 2012).

Ainda, sobre as mudanças referentes no aumento dos atrativos apresentados pelo Guia Brasil Quatro Rodas, cabe destacar a 'evolução' no número de atrativos contemplados nas categorias Compras, Parques e Praças e Passeios e Excursões e a queda no número de atrativos presentes dentro da categoria de construções históricas, museus e igrejas. Esse fato é corroborado com o que cita Rechia (2005) e Ramos, Gândara e Tramontin (2008) ao salientarem a relevante estratégia urbanística de Curitiba que buscou agregar paisagens naturais, modelos arquitetônicos 
modernos e projetos culturais nos espaços públicos destinados as práticas de lazer e de turismo faz com que esses 'atrativos' tornem-se mais divulgados ao turista, para que o mesmo observe a conotação da imagem de Curitiba de uma 'cidade que deu certo'. Na realidade o que se pode identificar é o surgimento de novos atrativos suplantando em relevância a atrativos que anteriormente eram os mais destacados.

Neste contexto, cabe destacar a classificação dos atrativos de Curitiba no Guia Brasil Quatro Rodas, nos anos de 1989, 2001 e 2013, para que se possa analisar a qualidade e até mesmo a importância que o guia destaca a cada atração turística divulgada por ele. Sendo assim, os resultados da análise de conteúdo referente a tal questão será apresentada no Quadro 06.

Quadro 06 - Classificação dos atrativos turísticos de curitiba - guia brasil quatro rodas

\begin{tabular}{|c|c|c|c|}
\hline & 1989 & 2001 & 2013 \\
\hline \multicolumn{4}{|l|}{ Compras } \\
\hline Atrativo & Classificação & Classificação & Classificação \\
\hline Artesanato Ucraniano & Sem Avaliação & Não Citado. & Não Citado \\
\hline Artesanato Polonês & Sem Avaliação & Não Citado. & Não Citado \\
\hline Artesanato do Paraná & Não Citado. & Sem Avaliação & Não Citado \\
\hline Feira da Praça da Espanha & Não Citado & Não Citado & Sem Avaliação \\
\hline Feira de Arte e Artesanato Popular & 01 estrela & Não Citado & Não Citado \\
\hline Feira de Artesanato - Largo da Ordem & Não Citado. & Sem Avaliação & Sem Avaliação \\
\hline Mercado Municipal & Não Citado & Não Citado & Sem Avaliação \\
\hline Shoppings & Não Citado & Não Citado & Sem Avaliação \\
\hline \multicolumn{4}{|l|}{ Eventos } \\
\hline Festa da Uva & Sem Avaliação & Não Citado & Não Citado \\
\hline Fenam (Feira Nacional da Madeira) & Sem Avaliação & Não Citado & Não Citado \\
\hline Revoada Nacional de Velas Águias & Sem Avaliação & Não Citado & Não Citado \\
\hline Salão da Mulher & Sem Avaliação & Não Citado & Não Citado \\
\hline Oficina de Música & Não Citado & Não Citado & Sem Avaliação \\
\hline Réveillon Popular & Sem Avaliação & Não Citado & Não Citado \\
\hline Feira Lar e Decoração & Sem Avaliação & Não Citado & Não Citado \\
\hline Festival Folclórico Internacional & Sem Avaliação & Não Citado & Não Citado \\
\hline Feira da Alimentação e Embalagem & Sem Avaliação & Não Citado & Não Citado \\
\hline Feira Brasileira do Artesanato & Sem Avaliação & Não Citado & Não Citado \\
\hline Festival de Teatro & Não Citado & Sem Avaliação & Sem Avaliação \\
\hline Quatro Giorni In Itália & Sem Avaliação & Não Citado & Não Citado \\
\hline Natal de Luz & Não Citado & Não Citado & Sem Avaliação \\
\hline Virada Cultural & Não Citado & Não Citado & Sem Avaliação \\
\hline Grande Prêmio do Paraná & Sem Avaliação & Não Citado & Não Citado \\
\hline \multicolumn{4}{|l|}{ Construções Históricas } \\
\hline Casa Romário Martins & 01 estrela & Não Citado & Não Citado \\
\hline Ruínas de São Francisco & 01 estrela & Não Citado & Não Citado \\
\hline Fundação Cultural & 01 estrela & Não Citado & Não Citado \\
\hline Galeria Schaeffer & 01estrela & Não Citado & Não Citado \\
\hline Teatro Paiol & Não Citado & 01 estrela & Não Citado \\
\hline Palácio Avenida & Não Citado & 01 estrela & Não Citado \\
\hline Setor Histórico de Curitiba & Não Citado & 01 estrela & 03 estrelas \\
\hline Solar do Barão & 01 estrela & 01 estrela & Não Citado \\
\hline
\end{tabular}


Quadro 06 - Classificação dos atrativos turísticos de curitiba - guia brasil quatro rodas

(continuação)

\begin{tabular}{|c|c|c|c|}
\hline & \multirow[t]{2}{*}{1989} & \multirow[t]{2}{*}{2001} & \multirow{3}{*}{$\frac{2013}{\text { Não Citado }}$} \\
\hline & & & \\
\hline $\begin{array}{l}\text { Igreja da Ordem de São Francisco das } \\
\text { Chagas }\end{array}$ & & 01 estrela. & \\
\hline Igreja do Rosário & 01 estrela & Não Citado & Não Citado \\
\hline Catedral Metropolitana & 01 estrela & 01 estrela & Não Citado \\
\hline \multicolumn{4}{|l|}{ Museus } \\
\hline Museu de Arte Sacra & 01 estrela & Não Citado & Não Citado \\
\hline Museu da Habitação do Imigrante & 02 estrelas & Não Citado & Não Citado \\
\hline Museu Ferroviário & 01 estrela & 01 estrela & 01 estrela \\
\hline Museu da Energia & 01 estrela & Não Citado & Não Citado \\
\hline Museu da Imagem e do Som & 01 estrela & Não Citado & Não Citado \\
\hline Museu David Carneiro & 01 estrela & Não Citado & Não Citado \\
\hline Museu do Expedicionário & 01 estrela & 01 estrela & 02 estrelas \\
\hline Museu Paranaense & 01 estrela & 02 estrelas & 03 estrelas \\
\hline Museu de Arte Contemporânea & 01 estrela & Não Citado & Não Citado \\
\hline Guido Viaro & 01 estrela & Não Citado & Não Citado \\
\hline Museu do Automóvel & 01 estrela & 01 estrela & Não Citado \\
\hline Museu de História Natural & Não Citado & 01 estrela & Não Citado \\
\hline Museu de Arte do Paraná & Não Citado & 01 estrela & Não Citado \\
\hline Museu Oscar Niemeyer & Não Citado & Não Citado & 04 estrelas \\
\hline Casa Alfredo Andersen & 01 estrela & Não Citado & Não Citado \\
\hline \multicolumn{4}{|l|}{ Parques } \\
\hline Jardim Botânico & Não Citado & 02 estrelas & 03 estrelas \\
\hline Parque Estadual do Marumbi & Não Citado & Não Citado & 03 estrelas \\
\hline Parque Tanguá & Não Citado & 02 estrelas & 03 estrelas \\
\hline Parque do Barigui & 01 estrela & 02 estrelas & 02 estrelas \\
\hline Bosque do Alemão & Não Citado & 02 estrelas & 02 estrelas \\
\hline Teatro Ópera de Arame & Não Citado & 02 estrelas & 02 estrelas \\
\hline Parque da Mônica & Não Citado & 02 estrelas & Não Citado \\
\hline Parque da Barreirinha & 01 estrela & Não Citado & Não Citado \\
\hline Passeio Público & 01 estrela & 01 estrela & 01 estrelas \\
\hline Parque Regional do Iguaçu (Zoológico) & 01 estrela & 01 estrela & Não Citado \\
\hline Jardins Ambientais & 01 estrela & Não Citado & Não Citado \\
\hline São Lourenço & 01 estrela & Não Citado & Não Citado \\
\hline Parque Passaúna & Não Citado & 01 estrela & Não Citado \\
\hline Parque Tingui & Não Citado & 01 estrela & 02 estrelas \\
\hline Universidade Livre do Meio Ambiente & Não Citado & 01 estrela & Não Citado \\
\hline Praça do Japão & Não Citado & 01 estrela & Não Citado \\
\hline Bosque João Paulo II & 01 estrela & 01 estrela & 02 estrelas \\
\hline \multicolumn{4}{|l|}{ Passeios/Excursões } \\
\hline Estância Ouro Fino & 01 estrela & Não Citado & Não Citado \\
\hline Linha Turismo & Não Citado & 02 estrelas & 03 estrelas \\
\hline Vila Velha & 03 estrelas & Não Citado & Não Citado \\
\hline Trem: Serra do Mar - Paranaguá & 02 estrelas & 03 estrelas & 04 estrelas \\
\hline $\begin{array}{l}\text { Viagem de "Maria Fumaça" - Curitiba - } \\
\text { Lapa }\end{array}$ & 01 estrela & Não Citado & Não Citado \\
\hline Viagem pela BR 277 para Paranaguá & 01 estrela & Não Citado & Não Citado \\
\hline Parque histórico da erva-mate & 01 estrela & Não Citado & Não Citado \\
\hline Estrada da Graciosa & 02 estrelas & Não Citado & 03 estrelas \\
\hline Passeio de Helicóptero & Não Citado & 01 estrela & Não Citado \\
\hline
\end{tabular}


Quadro 06 - Classificação dos atrativos turísticos de curitiba - guia brasil quatro rodas

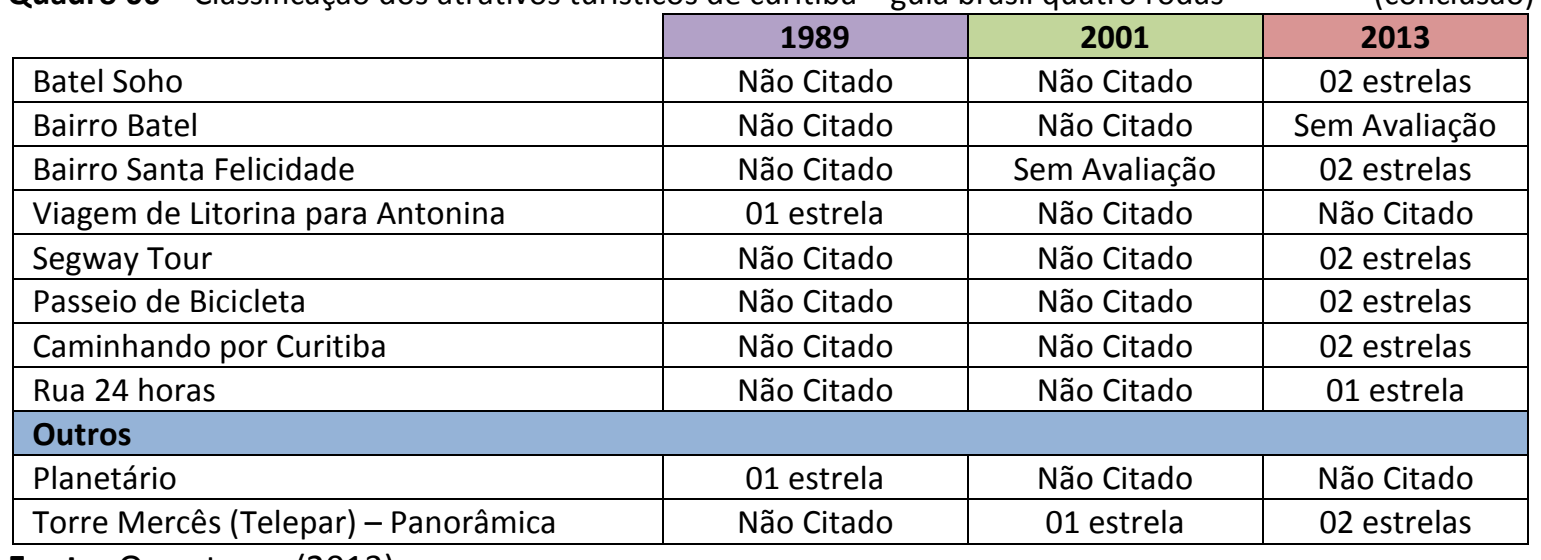

Fonte: Os autores (2013)

Com a análise do Quadro 06, podem-se identificar as mudanças dos atrativos turísticos divulgados pelo Guia Brasil Quatro Rodas, sendo assim, cabe destacar as questões mais relevantes oriundas da referida análise. As categorias compras e eventos possuem atrativos sem avaliação, porém a primeira contemplou um maior número de atrativos em 2013, sendo que a segunda destaca-se com o ano de 1989. Ao que se refere às construções históricas, percebe-se que o Setor Histórico da cidade é o único atrativo da cidade citado em 2013 e que conta uma avaliação de 03 estrelas. Já, as Igrejas citadas no Guia em 1989 e 2001 não constam nenhuma referência sobre as mesmas no ano de 2013. Pode-se inferir que na questão atrativos históricos, o que se destaca é o conjunto dos mesmos, e não aqueles isoladamente.

No que diz respeito aos museus de Curitiba, apesar de haver uma queda no número de atrativos apresentados no ano de 2013, dois museus foram bem avaliados no referido ano, sendo o Museu Paranaense com 03 estrelas e Museu Oscar Niemeyer com 04 estrelas, convertendo-o em um dos principais atrativos da cidade. Analisando-se os parques de Curitiba, principal atrativo da cidade, os guias mostram a melhora da avaliação destes nos anos pesquisados, destacando-se o Jardim Botânico e o Parque Tanguá com 03 estrelas e o Parque Estadual do Marumbi (3 estrelas), sendo este localizado no Litoral do Paraná, mostrando a importância do entorno da cidade para a atividade turística.

Por fim, no que se refere aos passeios e as excursões, pode-se perceber o aumento no número de atrativos analisados, sendo que os mais bem avaliados são a Linha Turismo (03 estrelas), que liga os principais pontos turísticos localizados na cidade de Curitiba, importante exemplo de serviço turístico que se converteu em atrativo e o Trem da Serra do Mar (04 estrelas) e a Estrada da Graciosa (3 estrelas), devendo-se destacar que os mesmos embora sendo passeios pelo entorno da cidade têm como ponto de partida Curitiba e que por isto devem ser considerados atrativos da cidade, além de contribuírem de forma relevante para aumentar a permanência dos turistas em Curitiba. A categoria outros contempla no ano de 2013, apenas a Torre Panorâmica como atrativo turístico, importante atrativo para ajudar ao turista a "compreender" melhor a cidade. 
Pode-se perceber que ao longo dos anos os atrativos turísticos tiveram mudanças no que tange sua classificação, nesse sentido, cabe destacar os parques e praças, que efetivamente são os atrativos mais visitados (Viaje Curitiba, 2012), pois os mesmos buscaram ao longo dos anos proverem aos turistas experiências com mais qualidade. Isto pode ser observado através da melhora na classificação de certos parques, bem como merece destacar a atratividade formada pelo conjunto de parques avaliados com 2 e 3 estrelas, o que conforma algo único e caracteriza a cidade de Curitiba. Apesar da política concentrada nas áreas verdes (Rechia, 2005), o atrativo turístico melhor classificado da cidade é o Museu Oscar Niemeyer, com 04 estrelas, considerado pelo Guia um atrativo que o turista não pode deixar de ir. Este fato demonstra que Curitiba possui um grande diferencial quando se trata de atrações turísticas que é a diversidade, podendo ser trabalhada a partir de outros vieses, além daqueles que estão enraizados em sua gestão pública.

Apesar do atrativo melhor classificado ser de âmbito cultural, é relevante salientar o conjunto de atrativos formado pelos parques da cidade, que segundo Pedron (2013) tornaram-se elementos que identificam a cidade, isto é, se converteram em componente de caracterização e diferenciação da mesma, principalmente ao apresentar e valorizar elementos relacionados ao ambiente natural e cultural, para que desse modo, tanto a comunidade local quanto os turistas se sintam 'conectados' com os atrativos de Curitiba.

Cabem ressaltar alguns atrativos que aparecem com 1 estrela em 1989, tais como a Feira de Arte e Artesantato Popular, a Galeria Schaeffer, a Viagem de "Maria Fumaça" - Curitiba - Lapa e a Viagem de Litorina para Antonina, que deixaram de existir, ou, por exemplo, os Jardins Ambientais, a Estância Ouro Fino e Vila Velha, que segundo a avaliação do guia atualmente não estão citados como atrativos turísticos relevantes de Curitiba, pois segundo os técnicos do Guia, outros mais relevantes foram surgindo ao longo do tempo.

\section{CONSIDERAÇÕES FINAIS}

Os atrativos turísticos são considerados parte integrante do destino turístico, pois geralmente é a partir deles que se desperta o desejo no turista de visitar determinada localidade. Assim, o presente estudo buscou compreender como o Guia Brasil Quatro Rodas apresenta a cidade para seus visitantes, analisando a descrição e o emprego de imagens da cidade na introdução do destino oferecida pelos guias analisados, bem como a avaliação empregada para cada atrativo.

A análise dos guias turísticos permitiu verificar que houve mudanças nas questões referentes à combinação entre imagens e descrição do destino que está sendo divulgado. Enquanto em 1989, o guia não trazia ao leitor nem imagens muito menos uma descrição a respeito do destino, os anos de 2001 e 2013 buscavam descrever os principais pontos evocados pela divulgação da própria cidade, sendo que, apenas em 2013, foram congregadas imagens e descrição de Curitiba, para que o leitor/turista obtivesse uma visão mais abrangente a respeito do que pode ser encontrado na cidade, despertando, assim, o imaginário deste. 
Sobre a evolução dos atrativos apresentado pelo Guia Brasil Quatro Rodas, pode-se perceber que houve um aumento no número de atrativos presentes nas categorias passeios e excursão e parques/praças e bosques demonstrando, assim, a importância dos atrativos turísticos relacionados à natureza e os passeios ofertados em Curitiba. Contudo, os atrativos das categorias relacionadas ao cunho cultural obtiveram uma queda em sua divulgação, porém melhoram ao que tange a sua classificação, podendo esse fato ser observado a partir da classificação do Museu Oscar Niemeyer, com 04 estrelas, em 2013 e do Setor Histórico com 3 estrelas.

Também, no que diz respeito, a classificação dos atrativos turísticos pode-se perceber mudanças resultantes das visitas realizadas pelos especialistas do Guia Brasil Quatro Rodas, demonstrando a preocupação em se ofertar ao turista uma experiência de qualidade, que contemplasse todos os tipos de turistas. A partir do que foi discutido, destaca-se que a pesquisa com os guias turísticos pode ser considerada enriquecedora, principalmente quando se discute e analisa a avaliação de como os mesmos apresentam a cidade tanto aos turistas reais quanto aos turistas potenciais. Nesse sentido, pesquisas futuras englobando os guias turísticos podem ser consideradas extremamente relevantes, sobretudo ao se discutir outros destinos turísticos, inclusive realizando comparações sobre como os mesmos são apresentados pelos guias e até mesmo outras características apresentadas, como a descrição dos atrativos presentes na cidade, para se obter um cenário mais completo sobre a imagem projetada e percebida do destino frente ao que vem sendo divulgado, podendo, ainda ser realizada comparações com os demais meios de divulgação dos destinos turísticos, tais como: revistas especializadas na divulgação, o material publicitário divulgado pelos órgãos responsáveis pela atividade turística, que também devem ser levados em consideração em estudos futuros.

\section{REFERÊNCIAS}

Alcaide, G. G., Feliu, C.B. (2008) Las publicaciones divulgativas como vehículo de difusión del patrimonio arqueológico: bibliografía de guías arqueológicas en España 1975- 2005. Pasos: Revista de Turismo e Patrimonio Cultural, v.6, n.1, 69-82.

Barreira, I. (2005) Os guias turísticos em Berlim. p.299-320. Tempo Social, Revista de Sociologia da USP, v.17, n.1. São Paulo.

Bassanezi, C. (1996) Virando as páginas, revendo as mulheres: revistas femininas e relações homem-mulher 1945-1964. Rio de Janeiro: Civilização Brasileira.

Bastos, S.R. Nova, M. R. (2012) Guias de viagem e de turismo da cidade de São Paulo (1924 e 1954): hospitalidade e patrimônio. Turismo em Análise, v. 03, n. 03, 509-526.

Bonfim, I. .O. B.; BAHL, M. (2012) A cidade de Curitiba (PR) - Brasil: O turismo e suas imagens simbólicas. Revista de Cultura e Turismo, ano 06 - n. 04, 72-85.

Castro, C. (2006) Narrativas e imagens do turismo no Rio de Janeiro. In: Velho, G. (Org.). Antropologia Urbana: cultura e sociedade no Brasil e em Portugal. 3. ed. Rio de Janeiro: Zahar Editores, 80-87. 
Cellard, A. (2008). A análise documental. In: Poupart, J. Et Al. A pesquisa qualitativa:enfoques epistemológicos e metodológicos. Petrópolis, Vozes.

Cheverst, K.; Mitchell, K.; Davies, N. (2002) The role of adaptive hypermedia in a contextaware tourist guide. Communications of the ACM - The Adaptive Web, v. 45, n. 5, 47-51.

Cooper, C.; Fletcher, J.; Wanhill, D. G.; Shepherd, R. (2001) Turismo, princípios e prática. Porto Alegre: Bookman.

Custódio, R. B. (2006) A Influência das Intervenções Urbanísticas na Atividade Turística da Cidade de Curitiba. Dissertação de Mestrado. Programa de Pós-Graduação em Gestão Urbana - PUC/PR. Curitiba.

Curran, K.; Connell, J. (2006) A location-based mobile tourist guide. Tourism and Hospitality Research, vol. 6, No. 2.

Dencker, A. F. M. (1998) Pesquisa em turismo: planejamento, métodos e técnicas, São Paulo: Futura.

EMBRATUR. (1992) Conceitos turísticos. EMBRATUR: Departamento de Estudos Econômicos, Divisão de Economia do Turismo, Brasília.

El-Seoud, S. A. El-Sofany, H. (2011) Mobile Tourist Guide - An Intelligent Wireless System to Improve Tourism, using Semantic Web. International Journal of Interactive Mobile Technologies, v. 5, N. 4, 4-10.

Engel, J. F.; Blackwell, R. D.; Miniard, P. W. (1995) Comportamento do Consumidor. Rio de Janeiro: Livros Técnicos e Científicos.

Fernandes, A.L.; Yamamoto, J. A.; Júnior, B. P. T. (2011) Aspectos Da Folheteria Turística Do Município De Porto Velho: Uma Análise de Conteúdo. In: Saber Científico, Porto Velho, 03 (1): 12 -52.

Fernandes, D. L.; Gândara, J. M. G.; Souza, T. A. (2011) A influência do planejamento urbano na percepção de visitantes e visitados e a formação da imagem de Curitiba. Seminário da Associação Nacional de Pesquisa em Turismo, Anais... Balneário Camburiú.

Ferreira, A. S. (2011) Guias Turísticos Impressos e suas Dimensões de Análise. Trabalho de Conclusão de Curso (Curso de Turismo), 120 f. Universidade Federal Fluminense, Rio de Janeiro.

Fairclough, N. (1995) Critical Discourse Analysis: the Critical Study of Language. London: Longman. Foucault, M. (1969) L'archéologie du savoir. Paris: Gallimard.

Fraise, E.; Pomporgnac, J-C.; Paillan, M. (1997) Representações e Imagens da Leitura. São Paulo: Editora Ática.

Gândara, J. M.G; Albach, V.M; Vieira, V. B. A (2008) Gestão Responsável de Unidades de Conservação e o Turismo: Uma Análise Comparativa entre Curitiba e Joinville. Anais do V SeminTUR - Seminário de Pesquisa em Turismo do MERCOSUL. Caxias do Sul.

Garafolo, G. (2012) Escenario discursivo y significados implícitos en una guía'para los verdaderos viajeros': el caso de la Guía Azul de Zaragoza. Pasos - Revista de Turismo y Patrimônio Cultural, vol. 10 № 4. Special Issue, 71-82. 
Garcia. F. E. S. (1996) O city marketing de Curitiba: cultura e comunicação na construção da imagem urbana. In DEL RIO, V.; OLIVEIRA, L. (orgs). Percepção Ambiental: a experiência brasileira. São Paulo. Studio Nobel.

Gómez, S. M. (2005) La política de la mirada: las representaciones de las guías turísticas de Bogotá en los treinta. Anuario Turismo y Sociedad, n. 4, 150-169.

GUIA BRASIL QUATRO RODAS (1989) Editora: Abril.

GUIA BRASIL QUATRO RODAS (2001) Editora: Abril.

GUIA BRASIL QUATRO RODAS (2013) Editora: Abril.

INSTITUTO MUNICIPAL DE TURISMO (2011) Pesquisa de demanda turística: perfil e opinião - Curitiba 2010. Curitiba.

Kenteris, M.; Gavalas, D.; Economou, D. (2009) An innovative mobile electronic tourist guide application. Personal And Ubiquitous Computing, vol. 13, 103-118.

Kushano, E. S.; Filippim, M. L.; Gândara, J. M. G. (2013) Turismo no Litoral do Paraná: A perspectiva do Guia Brasil Quatro Rodas. Revista Rosa dos Ventos, v. 5, n. 01, 60-76.

Mariani, S. C. B. (1993) Os primórdios da imprensa no Brasil. In: ORLANDI, P. Eni. Discurso Fundador - a formação do país e a construção da identidade nacional. Campinas: Pontes Editores.

Matos, A. C.; Santos, M. L. (2004) Os Guias de Turismo e a emergência do turismo contemporâneo em Portugal (dos finais do século XIX às primeiras décadas do século XX). Geo Crítica / Scripta Nova. Revista electrónica de geografía y ciencias sociales. Barcelona: Universidad de Barcelona, vol. VIII, núm. 167.

Michelini, C. B. M. C. (2006) As imagens do Brasil mediadas por guias de viagem. Patrimônio: Lazer e Turismo, v. 3, Santos (São Paulo).

Moirand, S. (2004) Le même et l'autre dans les guides de voyage au XXIe siècle". In: Baider, F.; Burger, M.; Goutsos, D. (Eds.), La Communication Touristique. Approches discursives de l'identité et de l'altérité, Paris: L'Harmattan, 151-172.

Morais, L. P. (2012) Sabores de viagem - as culinárias regionais nos guias turísticos entre 1966 e 1983. Revista Rosa dos Ventos, v. 4, n. 3, p. 317-334.

Narciss, S.; Korndle, H. (2008) Distributed cognition in technology-enhanced foreign language learning: Creating a web-based tourist guide for London. International Journal Of Psychology, v. 40, n.3, 281-307.

Nova, M. R., Bastos, S. (2008) Turismo na cidade de São Paulo: o guia turístico de 1924. In: Anais do V Seminário da ANPTUR - Associação Nacional de Pesquisa e Pós-Graduação em Turismo, Belo Horizonte.

Oliveira, K. C. L.; Decanini, M. M. S. (2002) Projeto e produção cartográfica do Guia Turístico eletrônico das represas paulistas para internet. Revista Brasileira de Cartografia, n. 54. 
PMC - Prefeitura Municipal de Curitiba. Secretaria Municipal do Meio Ambiente / Departamento de Parques e Praças. Áreas Verdes. Disponível em: <http://www.curitiba.pr.gov.br/Secretarias.aspx?svc=107>. Acesso em: 30 jul. 2013.

Pedron, M. (2013) A experiência dos turistas nos parques de Curitiba/PR. Dissertação de Mestrado - PósGraduação em Geografia, Universidade Federal do Paraná.

Pereiro, X. Conde, S. P. (2005) Turismo e oferta gastronômica na comarca de Ulloa (Galiza): Análise de uma experiência de desenvolvimento local. Pasos: Revista de Turismo y Patrimonio Cultural, v. 03, n. 1, 109-123.

Pérez, X. P. (2012) El turismo indígena Guna (Panamá): Imaginarios y regímenes de mentira de las guías turísticas internacionales. Estudios y perspectivas en Turismo, vol.21, no.4, 945-962.

Picone, M. L. A. (2013) La idea de turismo en San Carlos de Bariloche a través de dos guías (1938). Estudios y Perspectivas en Turismo, v. 22, n. 2, 198-215.

Popper, K. (1974) A lógica da pesquisa científica. São Paulo: Cultrix.

Ramos, S.E.V.C.; Gândara, J.M.G.; Tramontin, R. (2008) Turismo e planejamento urbano: uma análise sobre o caso de Curitiba. Anais do V Seminário da Associação Nacional de Pesquisa e Pós-Graduação em Turismo, Belo Horizonte.

Rechia, S. (2005) Espaço e planejamento urbano na sociedade contemporânea: políticas públicas e a busca por uma marca identitária na cidade de Curitiba. In: Revista Movimento, Porto Alegre, v. 11, n. 3, 49-66.

Ribeiro, R. Mạ. (2005) Planejamento Urbano, Espaços Públicos de Lazer e Turismo no Bairro Uberaba. Curitiba. 125 f. Dissertação (Mestrado em Geografia) Setor de Ciências da Terra da Universidade Federal do Paraná.

Ribeiro, R. Mā; Silveira, M. A. T. (2006) Planejamento Urbano, Lazer e Turismo: Os Parques Públicos em Curitiba - PR. Turismo - Visão e Ação, v,. 8 - n.2, 309 - 321.

Río, M. H.; Zùñiga, F. M. (2007) La construcción de la identidad andaluza percibida y proyectada como reclamo turístico: los libros de viaje y las guías turísticas del siglo XX (1920-1970). Revista HMiC: Història Moderna i contemporània, n. 05.

Santulli, F (2010) Dall' illic et tunc all'eterno presente: trasformazione delle strutture enunciative per la nascita di unnuovo genere testuale". In: CANALS, J. / LIVERANI, E. (Eds.), Viaggiar con la parola (pp. 103119). Milano: Franco Angeli.

Silva, R. R. S. (2012) Avaliação dos Equipamentos e Serviços Turísticos do Jardim Botânico, Curitiba, Paraná, (Brasil). Revista Turismo em Análise, v. 23, n. 01.

Torres, M. (2006) O Rio dos Viajantes: representação da cidade nos guia de turismo. In: XXIX CONGRESSO BRASILEIRO DE CIÊNCIAS DA COMUNICAÇÃO - UnB.

URBS-URBANIZAÇAO DE CURITIBA. Linha Turismo. Disponível em: <http://www.urbs.curitiba.pr.gov.br/PORTAL/linha_turismo/>. Acesso: jul. 2013. 
Valls, J-F. (1996) Las claves del mercado turístico. Cómo competir en el nuevo entorno. Bilbao: Deusto.

VIAJE CURITIBA (2012) Confira os atrativos mais visitados pelos passageiros da linha turismo. Disponível em: <http://ww.viajecuritiba.com.br/pt/noticia/31871/noticias/confira-os-atrativos-mais-visitados-pelospassageiros-da-linha-turismo->. Acesso em: jul. 2013.

Villanueva Ramos, S. E. (2010) A dinâmica da localização da hotelaria curitibana no período de 1966 a 2008. Tese apresentada para a obtenção do Título de Doutor no Programa de Pós Graduação em Geografia. Universidade Federal do Paraná, Paraná.

Zabalza, M. C. B. (2012) Descripción y narración en las primeras guías turísticas de Navarra (1904-1929). Pasos: Revista de Turismo y Patrimonio Cultural, v. 10, n. 4, Special Issue, 25-37. 